\title{
Leadership in an Agile Project Management Environment
}

\author{
Bruce D. Fischer \\ Elmhurst University \\ Loubna Charef \\ Elmhurst University
}

\begin{abstract}
This paper considers the leadership approaches used in agile project management teams in particular and agile organizations in general. It considers the importance for managers to choose the right leadership style for each specific contingency. A significant consideration is the amount of change and the expectation of innovation. Managers may improve their leadership ability by learning to adjust their leadership styles. Agile approaches are expanding not only because of their ability to respond to change and innovation, but because of the ability to respond quickly to the volatile, uncertain, complex, and ambiguous nature of the business environment that has become the "new normal". Hybrid project management solutions are emerging and need a contain combination of agile and traditional project leadership approaches.
\end{abstract}

Keywords: agile, project management, leadership, agile organizations, change management

\section{INTRODUCTION}

Agile project management originated in the software development industry with the need for short planning horizons that could adapt well to change. The use of agile is becoming more popular for other projects involving uncertainty and where changes are made for the customer as the project progresses (Fischer, 2019). Agile is increasingly extending beyond software and project management to a methodology for organizations to cope with today's turbulent customer-driven marketplace. Agile enables organizations to master continuous change. It permits firms to flourish in an increasingly volatile, uncertain, complex, and ambiguous world. This paper focuses on leadership in an agile environment from two perspectives: 1) project management and 2) agile adoption in non-project organizations.

\section{Background}

Agile project management stresses the use of servant leadership. This approach involves significant changes over traditional (waterfall) project management. Traditional project management is appropriate for projects that can be completely planned before work begins. Typically, the leadership style used for traditional project management is some version of command and control. Perhaps not always command, but certainly, control. Servant leadership is particularly suited for the complex and changing environment that is increasingly presented in projects. One of the four values in the Manifesto for Agile Software Development developed by Beck, et al. (2001) is "Responding to change over following a plan." When a project manager needs to staff a project, they typically borrow personnel from the existing organization. 
Since the project manager will normally not have the authority to make personnel decisions, they rely upon functional managers and second staff from their departments. There is often increased status associated with being selected to work on a project and being given the opportunity to work on a new undertaking with high visibility, so these benefits make being assigned to a project attractive for the person being selected. However, they will still report to the functional manager and get their raises and promotions from the functional manager. Therefore, the project manager has only informal authority over the personnel drawn from the existing organization, and they must use charismatic leadership to obtain the best personnel for their projects. The successful traditional manager must be an effective charismatic leader to compensate for the lack of formal authority in their position. They must be able to obtain results against the plan without formal authority.

\section{TRADITIONAL PROJECT MANAGEMENT LEADERSHIP}

Traditional project management is based on thorough and detailed planning. Then, project teams are expected to adhere to the plan. The time, cost, and scope of the work are closely monitored and controlled. It typically employs management by exception, with action taken only when there are deviations from the plan. When there is a deviation from the plan, the project manager must act decisively to deal with the change. This will require leadership, to be sure, and it is typically command and control leadership. There is little time for project slippage, cost overruns, or scope creep. There is not a great deal of discussion of leadership in the traditional project management literature. Plan the project and get the job done according to the plan is the general approach.

\section{Leadership Styles in Project Management}

The Project Management Body of Knowledge (PMBOK) lists six leadership styles as most common among the numerous leadership styles described in the literature (PMI, 2017). They are laissez-faire, transactional, servant leader, transformational, charismatic, and interactional. Although all of these leadership forms are used by project managers in different situations, servant leadership has increasingly become used since it is a requisite part of agile project management. According to the PMBOK (PMI, 2017), servant leadership "focuses on other people's growth, learning, development, autonomy, and wellbeing; concentrates on relationships, community and collaboration; leadership is secondary and emerges after service." Servant leadership stresses teamwork and relationships, and it especially puts other people first.

\section{Leadership of Teams}

Leadership of teams is a unique skill. It is dependent upon the requirements of the team and especially on the nature of its tasks. Sometimes, self-directed teams are the most effective. If the tasks are well defined and the outcomes are clearly stated, teams may lead themselves. However, certainty is not the norm for many types of projects. When uncertainty exists, change will be necessary. This requires greater leadership. But what type of leadership is required in the presence of uncertainty?

\section{Servant Leadership}

The writers of the Agile Manifesto adopted servant leadership as their means of dealing with the uncertainty presented in software development. They wanted their cross-functional teams to have more adaptive leadership to deal with the high uncertainty levels with planning cycles typically of only two weeks. Servant leadership provided support instead of control as the primary means of leading.

\section{Situational Leadership}

Project management requires leadership that fits the situation. It depends on the situation at hand and which type of leadership and strategies are best suited for each task. It may require leadership to control demanding plans for time, money, and scope. Or the prevalent leadership requirement may require more of a coach when there is a need for personal growth and change during the project. 


\section{Charismatic Leadership}

Leaders may need to be persuasive and charismatic to be able to interface with department heads in seconding staff to work on their projects. Good interpersonal skills are invaluable in dealing with stakeholder groups. Project managers often need to use different leadership styles. Sometimes the best style is to be a coach. Supportive coaching is the preferred leadership style for most employees, especially highly skilled and educated ones. They want to be empowered and to be able to make their own decisions. Autonomy and democracy are increasingly the preferred environments in the workplace. Employees want to be in control of their own work, and they respond best to efforts by leaders to empower them. They wish to be free to make their own decisions when they are sufficiently competent.

\section{Personal Characteristics Necessary for Leadership}

According to Peter Drucker (2011), a leader is someone who has followers. Whom do people follow then? Sometimes they follow charismatic leaders. People who are articulate and emotionally moving speakers tend to be natural leaders. Leaders who communicate a vision, especially when it is one of a noble cause, will attract followers. Project managers have to use informal authority often in dealing with a project's various stakeholders. It is necessary to be able to impress them with the importance of the project.

There are other personal qualities that leaders must possess in order to be effective. First and foremost is integrity. Everyone in a project manager's sphere of influence (including their superiors) wants to feel that the project manager can be trusted. Lack of integrity is a deal-breaker. Also important are respect and empathy for others. Listening well is as important as speaking well. Then responding to what is heard is imperative. Ethics are essential. This includes things like being on time, not asking someone to do a job that the leader wouldn't do themselves, and showing consideration for others. Project managers must demonstrate that they are willing to support their employees because they hold economic power over them. Leaders must possess many other personal qualities such as civility and fairness; the list goes on. Without them, there will not be trust and respect. Project managers need to continuously improve their personal qualities to gain the support of stakeholders. These personal characteristics are key to leading successful projects. They are the wellspring of leadership.

\section{The Current Leadership Zeitgeist}

Project management is in a position today in which employees expect to have more freedom. There is a strong labor market, and anyone with good education and a good work ethic can find a good job. The demand for project work is strong. These conditions translate into a seller's labor market, and project managers need to create an appealing organizational climate to attract workers. Digital communications have made telecommuting a strong option. Working in teams is becoming the norm. Artificial intelligence is rapidly displacing routine jobs. Contract employees are increasing in numbers. The use of agile project management and variants of it is increasing in project management beyond its original use within the computer software development industry. What is the current leadership zeitgeist for project management?

Today's project managers should consider using some variant of agile project management. That means that servant leadership should be considered. Remote workers require more output controls than traditional command and control models. Leaders need to use more digital communication media in their assignments and follow-up. Organizational cultures are more laissez-faire, and coaching is the leadership norm rather than order giving. Increasingly, the expectation of workers is that they may follow their own methods as long as they deliver the overall output specifications contained in the project plan.

\section{AGILE ORGANIZATIONS AND LEADERSHIP}

Organizations are adopting agile because they want to be innovative, increase the speed to deliver the product, meet customer demand, and increase team effectiveness. However, to successfully make the agile shift, there is a need for a shift in leadership concept. Leadership in project management is slightly different from that in a non-project organization. Project managers usually lack formal authority. There is a need for a new leadership approach in agile organizations. 
Leadership has many definitions that focus on different things. Some of these definitions focus on leader traits (Personality Theory), while others focus instead on behavior (Behavior Theory), and some focus on actions (Leader-Follower Theory) (Safonov, Maslennikov, \& Lenska, 2018). Traditional leadership practices are outdated and ineffective in an agile work environment. The impact of the conventional leadership theories that date back to the mid-19th century is still present in today's workplace. For an instant, the Great Man Theory is still present in many of today's practical assumptions about leadership; charismatic leadership theory is considered the new manifestation of the Great Man Theory (Safonov et al., 2018). Leadership is not found solely in the leader but occurs at the individual, dyadic, group, and organizational levels. In the current environment, everyone needs the competence, capacity, and confidence to lead at the moment, not just those whose titles, job descriptions, and compensation packages put them in traditional leadership positions.

\section{In Volatile Times - Agility Rules}

The 21 st century is characterized by innovation driven by the continuing digital revolution and expanding global markets (Horney, Pasmore, \& O'Shea, 2010). The role of leadership in an agile environment is increasingly becoming one of the creating moments of clarity and focus and at the same time keeping an eye on what is shifting and reacting to it. Leaders need to walk a fine line between these positions in order to be flexible and sufficiently focusing on keeping people motivated. Leaders are struggling with how best to lead in a VUCA world (Ruksana \& Ahmed, 2019). According to Horney et al., (2010) and Meyer (2016), the term VUCA, coined by the US Army War College, describes the dynamic nature of our world today and has caught on in a variety of organizational settings to describe a business environment characterized by:

- Volatility - The nature, speed, volume, magnitude, and dynamics of change.

- Uncertainty - The lack of predictability of issues and events.

- Complexity - The confounding of issues and the chaos that surround any organization.

- Ambiguity - The haziness of reality and the mixed meanings of conditions.

Most of the old rules do not apply now; boundaries around companies are shifting, forming global networks of complex stakeholder relationships. Leaders are required to complement full-time employees with part-timers, consultants, suppliers, and even customers as part of the broader definition of the company's workforce. VUCA leaders must see where they are going and also remain flexible about how they get there (Ruksana \& Ahmed, 2019). They must be self-aware about their strengths and weaknesses as leaders and be adaptable and open to change. They must work collaboratively and be excellent communicators to thrive in a complex VUCA environment.

\section{Agile Teams}

To understand the new leadership approach used in an agile environment, we must understand the agile team dynamic. The Agile Manifesto (2001) sets the framework for how agile project team members work together. Agile establishes self-organizing teams, where all members share responsibility for their performance as a whole (Medinilla, 2012). Agile teams are informal teams; they do not engage informalities that can waste time. For improvisers, the initial scene is often provided by the audience; for business players, they are set by the client and available resources. In both contexts, players co-create with the expectation that more givens will be discovered in the midst of the fast-paced collaboration.

Leaders in an agile environment represent the agile concept to their teams and the organization. They need to understand and embrace agile values and principles; they need to learn agility. It is made up of two interrelated dynamics: the ability to learn in the midst of action and the ability to draw on prior learning and experience for success in unfamiliar contexts (transferable learning). Leaders who possess competence, capacity, and confidence in these dynamics are more successful and are more likely to deliver results for their organizations (Meyer, 2016). However, learning agility is not simply the ability to think on your feet. Learning agility is the ability to access and apply lessons learned in one context to another. 


\section{NEW LEADERSHIP APPROACHES}

We are impressed with the positive aspects of servant leadership. Its emphasis on people is a necessary condition for exceptional project management. Sometimes the word "servant" is misunderstood. Perhaps supportive leadership would be a better term. Coaching would also be accurate. However, there is a need for a new leadership practice to enable the concept of self-organization, especially since agile is not limited to software development and project management practice. We suggest using the current agile leadership approach practiced in project management and the VUCA leadership skills (a VUCA world is confirmed by the features of volatility, uncertainty, complexity, and ambiguity) as guidelines for the new approach (Meyer, 2016).

We think that servant leadership is an excellent form of leadership for developing employees and building teams. Its focus on people first makes it the preferred leadership style for providing job satisfaction and motivating people. Certainly, motivating is a major construct of leadership. Its focus on employee development makes it more likely to adapt to change. However, a new leadership style is needed. We are concerned that the strict deadlines and structure required of most traditional projects cannot be met by using servant leadership in teams. Deadlines and budgets need to be met, and scope creep is always a threat. Therefore, some blend of the flexibility and motivational aspects of servant leadership is required while maintaining the benefits of strong control provided with planning and controlling required by following the PMBOK to the letter. In fact, when we talk to project managers in different organizations, we frequently hear that they are practicing their own version of agile. They adopt what works for their particular circumstances, and it often has evolved into a hybrid between agile and traditional project management.

\section{A Hybrid Model of Leadership}

We propose a model similar to Duncan (1976) in his seminal paper about the ambidextrous organization, which used the flexible organizational structure most suited for creative work, and then applied a more rigid organizational structure when the operations required efficiency and speed. In an empirical study, Zacher and Rosing (2015) found that innovation is optimized with the interaction between two complementary leadership behaviors when leaders switched between the styles to deal with the changing requirements of the innovation process. We intend to pursue this theory further by observing and measuring organizations' results when leaders consciously shift between two styles depending on the degree of change required in a project. Our expectation is that leaders should practice contingency leadership that includes at least two forms of leadership style. One, involving control, is applied when there is a need for speedy performance, cost control, and to avoid scope creep. Another style, which might be a version of servant leadership, is applied when there is a need for change and innovation. We further hypothesize that the findings concerning contingency leadership may be generalizable to non-project organizations as well.

\section{Summary}

Leadership is the least specific of a project manager's functions but not the least important. Software development projects that require working with the customer and collaborating in cross-functional teams rely on servant leadership to be creative and agile. Traditional project management is more structured, and leaders rely on planning and control to implement projects. When projects are more complex, and change is more commonplace, more innovation is required. This requires leaders who can adapt their leadership style to the specific needs of a project. Flexibility is most effective in the creative aspects of a project, and more structure is needed for implementation. Leaders must be able to change their leadership style to adjust to the various contingencies of a project. 


\section{REFERENCES}

Beck, K., Beedle, M., Van Bennekum, A., Cockburn, A., Cunningham, W., Fowler, M., . . Kern, J. (2001). The agile manifesto. Retrieved from http://agilemanifesto.org/

Drucker, P.F., Goleman, D., \& George, B. (2011). HBR's 10 Must Reads on Leadership (with featured article "What Makes an Effective Executive," by Peter F. Drucker). Harvard Business Press, pp. $23-36$.

Duncan R.B. (1976). The ambidextrous organization: Designing dual structures for innovation. In R.H. Kilmann, L.R. Pondy, \& D. Slevin (Eds.), The management of organization design: Strategies and implementation (pp. 167-188). New York: North Holland.

Fischer, B.D. (2019). Using agile for innovation projects. Proceedings of the 2019 MBAA International Conference, Chicago, Illinois, March 27-29.

Horney, N., Pasmore, B., \& O’Shea, T. (2010). Leadership agility: A business imperative for a VUCA world. People \& Strategy, 33(4), 32-38.

Medinilla, Á. (2012). Agile management: Leadership in an agile environment. Springer Science \& Business Media.

Meyer, P. (2016). Agility shift: Creating agile and effective leaders, teams, and organizations. Routledge.

Project Management Institute. (2017). A guide to the Project Management Body of Knowledge (PMBOK guide) (6th ed.). Project Management Institute.

Ruksana, S., \& Ahmed, B. (2019). Developing leaders in VUCA: A case study. International Journal of Advanced and Innovative Research, 16.

Safonov, Y., Maslennikov, Y., \& Lenska, N. (2018). Evolution and modern tendencies in the theory of leadership. Baltic Journal of Economic Studies, (1), 304. https://doiorg.lopes.idm.oclc.org/10.30525/2256-0742/2018-4-1-304-310

Zacher, H., \& Rosing, K. (2015). Ambidextrous leadership and team innovation. Leadership \& Organization Development Journal, 36(1), 54-68. https://doi.org/10.1108/LODJ-11-2012-0141 